\title{
Do combate à febre amarela à defesa da saúde como direito: os cem anos da OPAS
}

KENNETH R. DE CAMARGO JR.*

\author{
CUETO, Marcos. \\ El valor de la salud: \\ historia de la Organización Panamericana de la Salud. \\ Washington, DC:OPS, 2004. \\ (Publicación Científica y Técnica No. 600)
}

A Organização Pan-mericana da Saúde tem desempenhado papel significativo desde sua fundação, há mais de um século, transitando do foco sobre as endemias e regulamentos sanitários que se constituíam em obstáculo ao comércio para uma atuação cada vez mais abrangente.

Marcos Cueto transformou a trajetória dess instituição secular numa narrativa fluida, de leitura agradável, sem perda de profundidade ou consistência. É impressionante como Cueto consegue conciliar o story telling com uma fina análise na qual, desde os determinantes mais abrangentes, como as necessidades econômicas do comércio intra e intercontinental ou a cambiante política externa norte-americana, são entrelaçados os detalhes das biografias e carreiras dos sucessivos diretores.

Nesse livro, produzido por demanda da própria OPAS, Cueto optou por tomar como ponto de partida as figuras históricas de seus primeiros dirigentes, sanitaristas visionários que conseguiram mesmo em condições adversas manter em funcionamento a mais antiga das instituições internacionais de saúde, e logrando evitar sua simples incorporação pela OMS quando da criação da mesma no período pós-Segunda Guerra Mundial.

O livro narra conquistas técnicas importantes, que contaram com o suporte decisivo da OPAS, escudada no trabalho de cientistas do próprio continente, como Finlay e Chagas, desde o apoio ao controle da febre amarela à erradicação da varíola e da pólio no continente; ou ainda na difusão da proposta da atenção primária, denunciando ao mesmo tempo as tentativas de reduzi-la a 
uma medicina pobre para populações pobres. É dado justificado destaque ao apoio da OPAS à criação da BIREME, de fundamental importância para pesquisadores, professores e profissionais de saúde do Brasil e demais países da América Latina e Caribe.

Destaca-se ainda a crônica do surgimento do método CENDES/OPAS, inspirado pelo pensamento cepalino e no contexto da guerra fria, em parte como contraposição tanto à ideologia da revolução cubana quanto à hegemonia norte-americana.

Mas talvez o aspecto mais relevante da trajetória da OPAS seja sua relevante contribuição para a difusão do ideal de saúde como direito, da qual o próprio SUS brasileiro é tributário.

Pela relevância da instituição abordada, bem como pela riqueza de fontes e profundidade da análise, o livro de Cueto se impõe como referência para a Saúde Coletiva.

\section{NOTA}

* Professor adjunto no Departamento de Planejamento e Administração em Saúde do IMSUERJ; editor de Physis: Revista de Saúde Coletiva. Endereço eletrônico: kenneth@uerj.br. 